\title{
Chk1 knockdown confers radiosensitization in prostate cancer stem cells
}

\author{
XIAOBIN WANG ${ }^{1}$, ZHIKUN MA $^{2}$, ZHENG XIAO $^{3}$, HUI LIU ${ }^{1}$, \\ ZHONGLING DOU ${ }^{1}$, XIAOSHAN FENG ${ }^{2}$ and HAIJUN SHI ${ }^{1}$ \\ Departments of ${ }^{1}$ Urology, ${ }^{2}$ Oncology and ${ }^{3}$ Neurosurgery, The First Affiliated Hospital of \\ Henan University of Science and Technology, Luoyang 471003, P.R. China
}

Received June 25, 2012; Accepted September 18, 2012

DOI: $10.3892 / o r .2012 .2068$

\begin{abstract}
Radioresistance is responsible for treatment failure after radiotherapy in localized prostate cancer, while prostate cancer stem cells promote radioresistance by preferential activation of the DNA damage response. Chk1 inhibition has been shown to sensitize many tumor cells to radiation. However, whether Chk1 inhibition can potentiate the cytotoxic effects of radiation on prostate cancer stem cells remains to be elucidated. In this study, $\mathrm{CD} 133^{+} \mathrm{CD} 44^{+}$cells were isolated using microbeads and were found to possess cancer stem cell properties. Using shRNA, Chk1 was knocked down in the sorted $\mathrm{CD} 133^{+} \mathrm{CD} 44^{+}$cells. Our results demonstrated that Chk1 knockdown abrogated the radiation-induced G2/M arrest, inhibited DNA damage repair and promoted premature mitosis, leading to increased apoptosis in the radiated sorted $\mathrm{CD} 133^{+} \mathrm{CD} 44^{+}$cells. Moreover, these effects were accompanied by caspase-2 activation and the inactivation of phosphorylated Cdc25C and Cdc2. Our results suggest that Chk1 knockdown increases the radiosensitivity of $\mathrm{CD} 133^{+} \mathrm{CD} 44^{+}$prostate cancer stem cells. Chk1 knockdown in prostate cancer stem cells may be an effective therapeutic strategy against prostate cancer.
\end{abstract}

\section{Introduction}

Prostate cancer is the second leading malignancy in the Western world (1). Radiation is the mainstay of conventional prostate cancer treatment and it is likely to remain as such in the foreseeable future (2). Unfortunately, in our clinical practice, radioresistant prostate cancer was observed in approximately $20-30 \%$ of patients treated with primary radiation therapy for clinically localized prostate cancer, leading to cancer-related mortality in at least $27 \%$ of patients within 5 years (3). It is known that the radiation doses in prostate cancer treatment are generally limited to less than 80 Gy due to intolerable toxicity

Correspondence to: Dr Haijun Shi, Department of Urology, The First Affiliated Hospital of Henan University of Science and Technology, 24 Jinghua Road, Luoyang 471003, P.R. China

E-mail: urololy@yahoo.cn

Key words: prostate cancer, Chk1, cancer stem cells, apoptosis at higher doses; however, the radioresistance of prostate cancer cells has significantly reduced the therapeutic effect of the limited amount of radiation (4).

Previous studies have demonstrated that the DNA damage response pathway plays a dominant role in conferring radioresistance and its key mediator, Chk1, has been recognized as the culprit for radioresistance development $(5,6)$. When activated, Chk1 phosphorylates a plethora of effector molecules involved in cell cycle arrest, DNA repair and apoptosis, which triggers cell cycle checkpoint and DNA repair defects, resulting in radiation hypersensitivity (7). Thus, restraining Chk1 activity may translate into improvement in the overall efficacy of radiation.

Apart from Chk1, it is believed that cancer stem cells are predisposed to radioresistance due to their preferential activation of the DNA damage checkpoint response and increasing DNA repair capacity (8-10). Indeed, radiation has been shown to kill differentiated tumor cells while sparing the rare cancer stem cells (11). Since cancer stem cells possess the capacity of self-renewal, multilineage differentiation and maintained proliferation, the presence of a small fraction of cancer stem cells that have survived radiation tend to put patient at a higher risk of tumor regrowth and recurrence (12-14).

In our previous study, we reported that Chk1 knockdown improved the radiosensitivity of glioblastoma stem-like cells (15). These aforementioned data lead us to infer that restraining Chk1 activity may sensitize prostate cancer stem cells to radiation therapy; however, evidence supporting this hypothesis is lacking. In this study, using Chk1 knockdown, we investigated whether restraining Chk1 activity is associated with the radiosensitization of prostate cancer stem cells. Our results demonstrate that the isolated $\mathrm{CD} 133^{+} \mathrm{CD} 44^{+}$subpopulation from DU145 human prostate cancer cells present the key biological properties of cancer stem cells. Chk1 knockdown potentiates the cytotoxic effects of radiation on $\mathrm{CD} 133^{+} \mathrm{CD} 44^{+}$ prostate cancer stem cells by abrogating G2 arrest, as well as increasing apoptosis. Furthermore, the $\mathrm{Cdc} 25 \mathrm{c}-\mathrm{Cdc} 2$ pathway may be associated with Chk1 knockdown-mediated cell cycle arrest abrogation, while the induced apoptosis may be associated with caspase- 2 activation in $\mathrm{CD} 133^{+} \mathrm{CD} 44^{+}$prostate cancer stem cells. To our knowledge, this study presents the first description of the effects of Chk1 restraining activity on the radiosensitivity of prostate cancer stem cells, and may provide a broad therapeutic paradigm against prostate cancer. 


\section{Materials and methods}

Cell culture. The DU145 human prostate cancer cell line was obtained from ATCC and was maintained in RPMI-1640 medium supplemented with $10 \%$ fetal bovine serum in a humidified incubator $\left(37^{\circ} \mathrm{C}, 5 \%\right.$ carbon dioxide). Purified $\mathrm{CD}_{133}{ }^{+} \mathrm{CD} 44^{+}$prostate cancer stem cells were cultured DMEM/ F12 medium supplemented with $20 \mathrm{ng} / \mathrm{ml}$ EGF, $10 \mathrm{ng} / \mathrm{ml} \mathrm{bFGF}$, $5 \mathrm{mg} / \mathrm{ml}$ insulin and $0.4 \%$ BSA. For sphere formation, cells were suspended and plated at 1,000 cells $/ \mathrm{ml}$ per well in 24-well low-attachment plates and were analyzed after 7-14 days. For differentiation, $5 \%$ fetal bovine serum was added and the growth factor was deleted from the culture medium. The $\mathrm{CD} 133^{+} \mathrm{CD} 44^{+}$ prostate cancer stem cells were then cultured for analysis.

shRNA preparation. As described in our previous study (15), we designed the interferential sequence Chk1-shRNA based on the target sequences of the Chk1 gene (GenBank GI: 166295195). The Chk1 shRNA sequences were as follows: 5'-CCG GCT GCA AAT AGT AGT TCC TGA ACT CGA GTT CAG GAA CTA CTA TTT GCA GTT TTTG-3' (forward) and 5'-AAT TCA AAA ACT GCA AAT AGT AGT TCC TGA ACT CGA GTT CAG GAA CTA CTA TTT GCAG-3' (reverse). The mock shRNA sequences were: 5'-GAT CCC CGT TCT CCG AAC GTG TCA CGT TTC AAG-3' (forward) and 5'-AGA ACG TGA CAC GTT CGG AGA ATT TTT TGG AAA-3' (reverse). The above-mentioned shRNAs were ligated into the pLKO.1-TRC vector and the Chk1-shRNA, and the mock-Chk1 plasmids were then formed. The cells were transiently transfected with $2 \mu \mathrm{g}$ plasmids via Lipofectamine 2000 (Invitrogen) according to the manufacturer's instructions. The knockdown efficiency was confirmed by RT-PCR and western blot analysis.

Isolation. DU145 cells were cultured under normal conditions. Subsequently, $10^{8}$ cells were suspended in magnetic microbeads buffer in a final volume of $600 \mu \mathrm{l}$. FcR blocking reagent $(200 \mu \mathrm{l})$ and $200 \mu \mathrm{l}$ CD44 MACS microbeads were then added to the suspension sequentially. The suspension was then mixed and incubated for $15 \mathrm{~min}$ at $4^{\circ} \mathrm{C}$. The column was subsequenlty placed in the magnetic flied of a MACS Separator and washed with $3 \mathrm{ml}$ buffer. For the following step, the cell suspension was loaded onto the column and the negative cells were allowed to pass though and the column was then rinsed with $3 \mathrm{ml}$ buffer three times. The column was placed on a collection tube and $5 \mathrm{ml}$ of buffer were pipetted onto the column and the positive fraction was flushed out. The positive fraction was then eluted with buffer and the CD44 cells were obtained. The cells were sorted again with CD133 MACS microbeads as described above.

Flow cytometry. For surface marker identification, the expression of the CD133 and CD44 markers on DU145 cells was determined by flow cytometry after surface staining with anti-human CD133 and CD44 antibodies, respectively. Flow cytometry was performed on a FACSCanto II (BD Biosciences) and analyzed using BD FCSDiva Software and FCS Express 4 software (De Novo Software, Los Angeles, CA). For cell cycle analysis, the cells were harvested and fixed in $75 \%$ ethanol at $4{ }^{\circ} \mathrm{C}$ overnight. Next day, cells were suspended in $20 \mu \mathrm{l} \mathrm{PBS}$ and $10 \mu \mathrm{l}$ RNase A $(5 \mathrm{mg} / \mathrm{ml})$. After 30-min incubation, PI $(500 \mu \mathrm{g} / \mathrm{ml})$ was added and the cells were incubated for $30 \mathrm{~min}$ in the dark for analysis. For apoptosis analysis, the cells were suspended in Annexin V-FITC binding buffer $(195 \mu \mathrm{l})$ and Annexin V-FITC $(5 \mu \mathrm{l})$ in the dark for $10 \mathrm{~min}$. The cells were centrifuged and suspended in binding buffer $(190 \mu \mathrm{l})$ and $10 \mu \mathrm{l}$ PI solution on ice in the dark for analysis.

EdU assay. The 96-well plate was centrifuged (1,000 rpm for $5 \mathrm{~min})$. Subsequently, $100 \mu \mathrm{l} \mathrm{EdU}(50 \mu \mathrm{M})$ were added into each well followed by mixture. After incubation for $2 \mathrm{~h}$, the supernatant was removed. The cells were washed with PBS and fixed using $4 \%$ buffered formaldehyde for $30 \mathrm{~min}$. The cells were cultured in $4 \%$ glycine for $5 \mathrm{~min}$. After washing with PBS, the cells were permeabilized with $0.5 \%$ Triton $\mathrm{X}-100$ for 5 min followed by washing with PBS. The cells were then stained with Apollo staining reagent $(100 \mu l)$ and incubated for $30 \mathrm{~min}$. After permeabilization for $30 \mathrm{~min}$, the cells were washed with $100 \mu \mathrm{l}$ methanol, followed by washing with PBS. The cells were then incubated with $100 \mu$ l Hoechst 33342 for $30 \mathrm{~min}$. After washing with PBS, the wells were viewed and photographed using a confocal fluorescence microscope (Olympus FV500; Olympus, Tokyo, Japan). The staining positive rate was counted as positive cells/overall cells $\times 100 \%$. For each sample, the cell number was counted at least three times.

Western blot analysis and RT-PCR. The procedure and reagent for western blot analysis and RT-PCR has been described in our previous study (16). The anti-Chk1 (1:1,000; Santa Cruz Biotech, Santa Cruz, CA), anti-Rad51 (1:1,000; Santa Cruz Biotech), anti-pH3 (1:500; Upstate Biotechnology, Lake Placid, NY), anti- $\gamma$-H2AX (1:500; Upstate Biotechnology, Milford, MA), anticaspase-2 (1:1,000; Cell Signaling, Danvers, MA), anti-pCdc25C (1:1,000; Cell Signaling), anti-pCdc2 (1:1,000; Cell Signaling) and anti-GAPDH antibodies (1:3,000; Santa Cruz Biotech) were used. In this study, we employed the following primers for RT-PCR: human Chk1 forward, 5'-ATG CTC GCT GGA GAA TTG C-3' and reverse, 5'-ATA AGG AAA GAC CTG TGC GG-3'; and human GAPDH forward, 5'-ACG GAT TTG GTC GTA TTGGG-3' and reverse, 5'-TGA TTT TGG AGG GAT GTCGC-3'.

Statistical analysis. Statistical analyses were performed using statistical software SPSS 13.0. Data are expressed as means \pm SD. The student's t-test and variance analysis were used in this study. P-values $<0.05$ were considered to indicate statistically significant differences.

\section{Results}

Isolation and identification of prostate cancer stem cells. Since Chk1 inhibition radiosensitizes tumor cells in a p53-dependent manner with an obvious effect on p53 mutant tumor cells (17-19), in this study, we employed the p53 mutant DU145 human prostate cancer cell line to isolate prostate cancer stem cells. As CD133 and CD44 have been recognized as the markers of prostate cancer stem cells (20-24), we analyzed the ratio of the $\mathrm{CD} 133^{+} \mathrm{CD} 44^{+}$subpopulation in DU145 cells using flow cytometry prior to isolation. As shown in Fig. 1A, the percentages of the $\mathrm{CD} 133^{+} \mathrm{CD} 44^{+}, \mathrm{CD} 44^{+}$and $\mathrm{CD} 133^{+}$ cell subpopulations in the total DU145 cells were $0.51 \pm 0.14$, $32.21 \pm 6.1$ and $0.81 \pm 0.23 \%$, respectively, confirming the exis- 


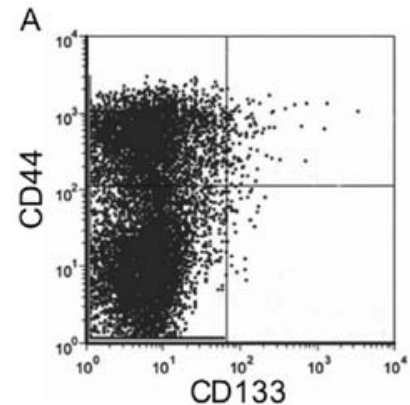

B

C

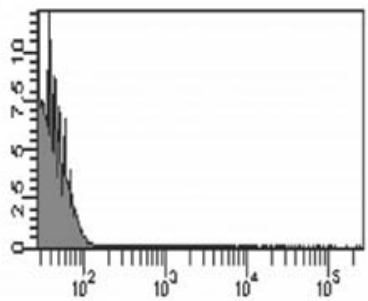

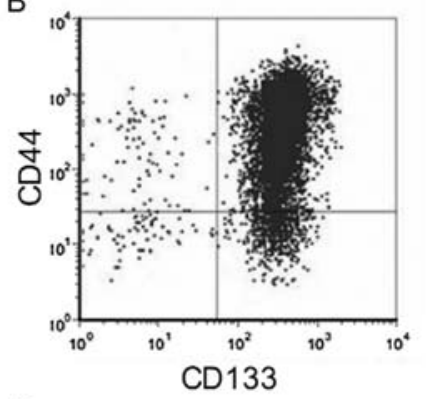

D

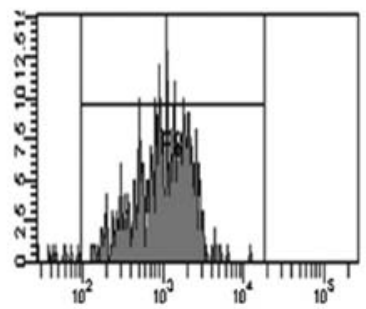

Figure 1. Isolation of $\mathrm{CD} 133^{+} \mathrm{CD} 44^{+}$cells from the DU145 cell line. (A) Rrepresentative cytometric dot-plots of CD44 and CD133 expression on DU145 cells. (B) Representative cytometric dot-plots of CD44 and CD133 expression on $\mathrm{CD} 133^{+} \mathrm{CD} 44^{+}$isolated cells from DU145 cells. (C and D) The representative flow cytometry histograms of the purity of the $\mathrm{CD} 133^{+} \mathrm{CD} 44^{+}$ isolated cells. The purity of the $\mathrm{CD} 133^{+} \mathrm{CD} 44^{+}$cells in the total isolated cells was found to be $85-92 \%$.

tence of a subpopulation of prostate cancer stem cells in the DU145 cells. We then isolated $\mathrm{CD} 133^{+} \mathrm{CD} 44^{+}$cells from the DU145 cells using CD44 microbeads and CD133 microbeads sequentially. As there is significantly greater number of CD44

than $\mathrm{CD}_{133^{+}}$cells in the DU145 cell line, we first used CD44 microbeads to isolate the $\mathrm{CD}_{4} 4^{+}$cells from the total DU145 cells. The obtained purified $\mathrm{CD} 44^{+}$cells were resuspended and sorted again using $\mathrm{CD}_{133^{+}}$microbeads. Subsequently, using flow cytometry, we determined the purity of the $\mathrm{CD} 133^{+} \mathrm{CD} 44^{+}$ cells in the obtained isolated cells and found that the purity of the $\mathrm{CD} 133^{+} \mathrm{CD} 44^{+}$cells ranged between $85-92 \%$ (Fig. 1B-D).

After isolation, we identified the stem cell properties in the $\mathrm{CD} 133^{+} \mathrm{CD} 44^{+}$isolated cells. As expected, a small number (500 cells) of $\mathrm{CD} 133^{+} \mathrm{CD} 44^{+}$isolated cells generated prostaspheres (Fig. 2A). Furthermore, some spheroids generated new prostaspheres, indicating the self-renewal ability of these cells (Fig. 1B). In addition, after exposure to normal medium, many spheroid cells grew as a flat monolayer with a morphology similar to DU145 cells after 10 days, showing the differentiation capacity (Fig. 1C). More importantly, a very small number of cells $(6,000$ cells) formed xenograft tumors in nude mice (Fig. 1D). These observation support the evidence that $\mathrm{CD} 133^{+} \mathrm{CD} 44^{+}$cells isolated from DU145 cells have cancer stem cell properties.

Knockdown of Chkl in prostate cancer stem cells using Chk1 shRNA. In our previous study, the shRNA-Chk1 plasmid was used successfully to knockdown Chk1 in glioblastoma stemlike cells (15). In this study, the same plasmid was employed to knockdown Chk1 in $\mathrm{CD} 133^{+} \mathrm{CD} 44^{+}$cells. The electrophoresis pattern of the shRNA-Chk1 plasmid digested for sequencing analysis, confirmed the base sequences (Fig. 3A and B). Using the Lipofectamine 2000 system, the cells were transiently transfected with the pLKO.1-Chk1 and pLKO.1-mock plasmids, and the inhibition efficiency was confirmed using RT-PCR and western blot analysis (Fig. 3C).
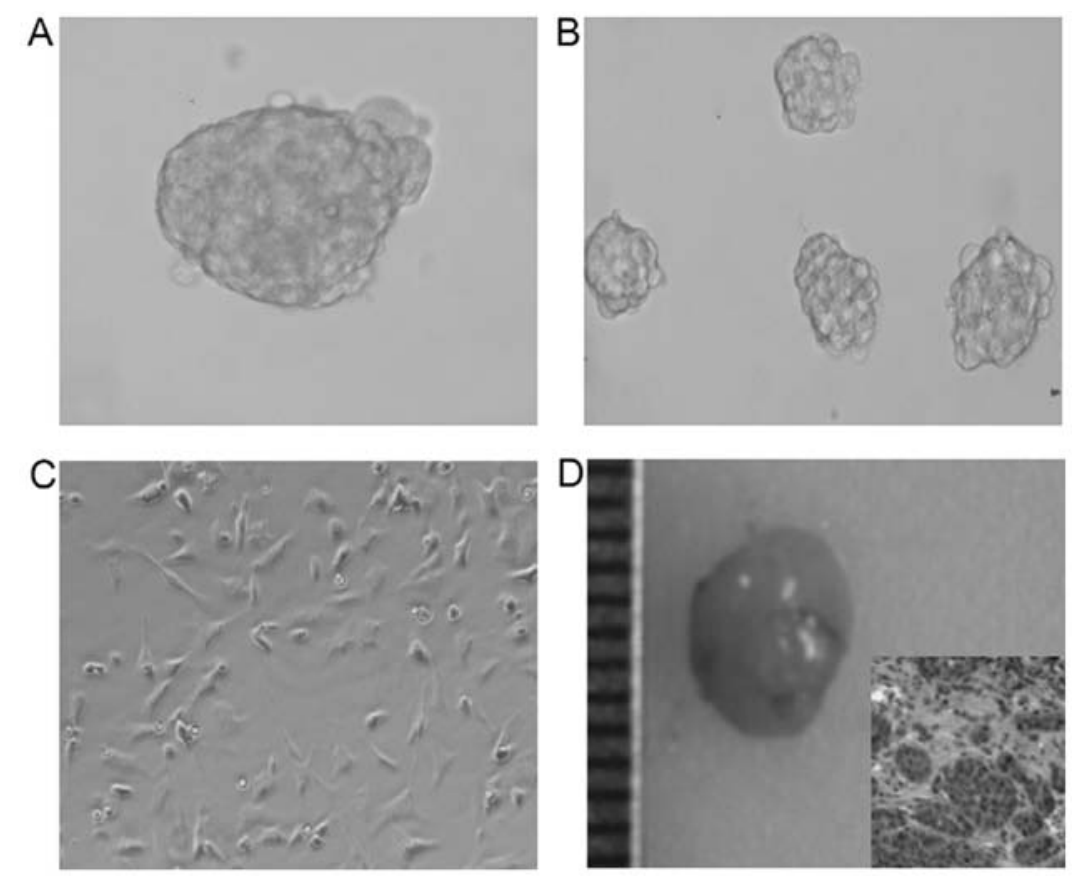

Figure 2. Culture and characterization of the $\mathrm{CD} 133^{+} \mathrm{CD} 44^{+}$cells from the DU145 cell line. (A) Culture of isolated CD133 ${ }^{+} \mathrm{CD} 44^{+}$cells growing as nonadherent prostaspheres. (B) Spheroids of $\mathrm{CD} 133^{+} \mathrm{CD} 44^{+}$cells generated new prostaspheres, suggesting the self-renewal capacity of the spheroids. (C) The differentiation capacity of the spheroids of $\mathrm{CD} 133^{+} \mathrm{CD} 44^{+}$cells. Serum supplementation and the withdrawal of growth factors induce the growth of spheroid cells as adherent cells with morphology similar to the bulk DU145 cells. (D) The high tumorigenic ability of CD133 ${ }^{+} \mathrm{CD} 44^{+}$cells. The overall view and the $\mathrm{H} \& \mathrm{E}$ staining of tumors generated from $6,000 \mathrm{CD} 133^{+} \mathrm{CD} 44^{+}$cells in nude mice. 

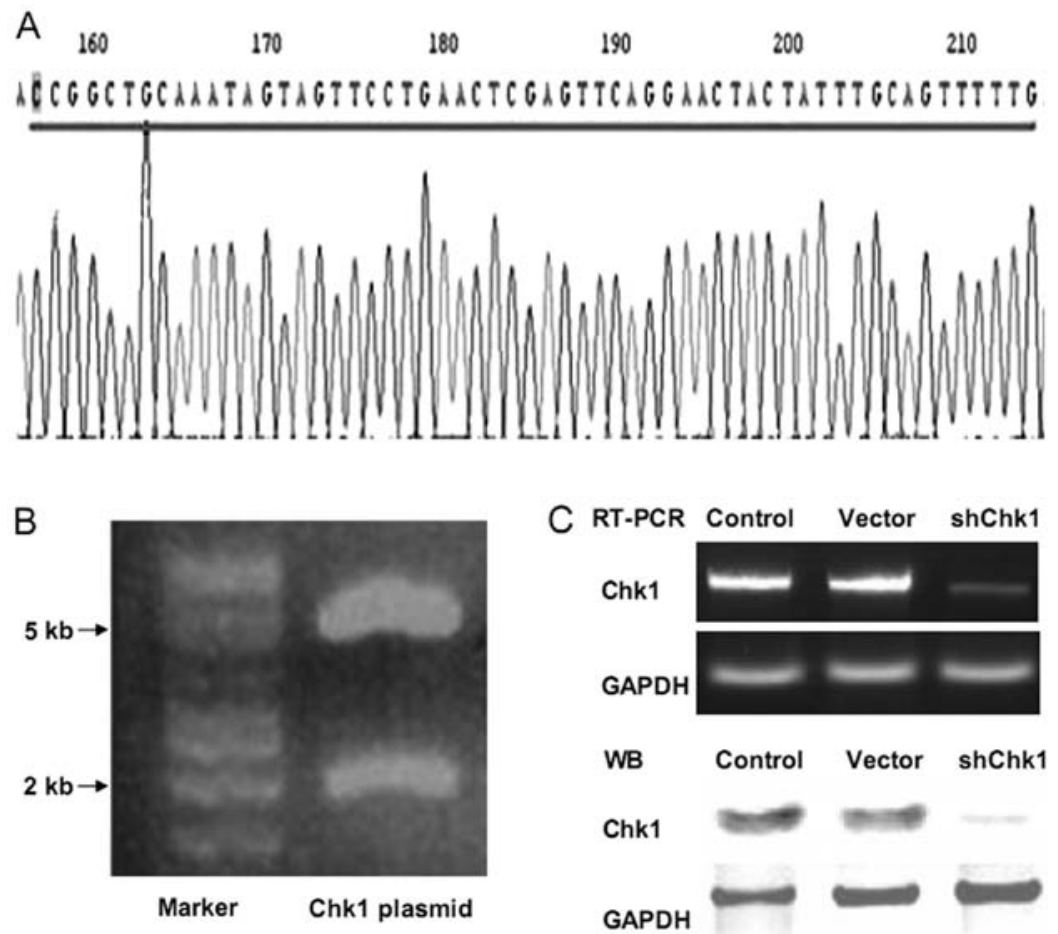

Figure 3. Identification of the recombinant plasmids. (A) Identification of the recombinant plasmids by DNA sequencing. pLKO.1-Chk1 sequences: $58 \mathrm{nt}$ (157-214) inserted sites. The sequences coincide with Chk1 gene retrieved from GenBank (GI: 166295195). (B) The plasmids were digested with EcoRI and $N c o I$; bands of 5 and $2 \mathrm{~kb}$ can be seen from the electrophoresis pattern, indicating that the vectors were constructed successfully. (C) Knockdown effect of Chk1 shRNA on $\mathrm{CD} 133^{+} \mathrm{CD} 44^{+}$cells was confirmed by RT-PCR and western blot analysis.

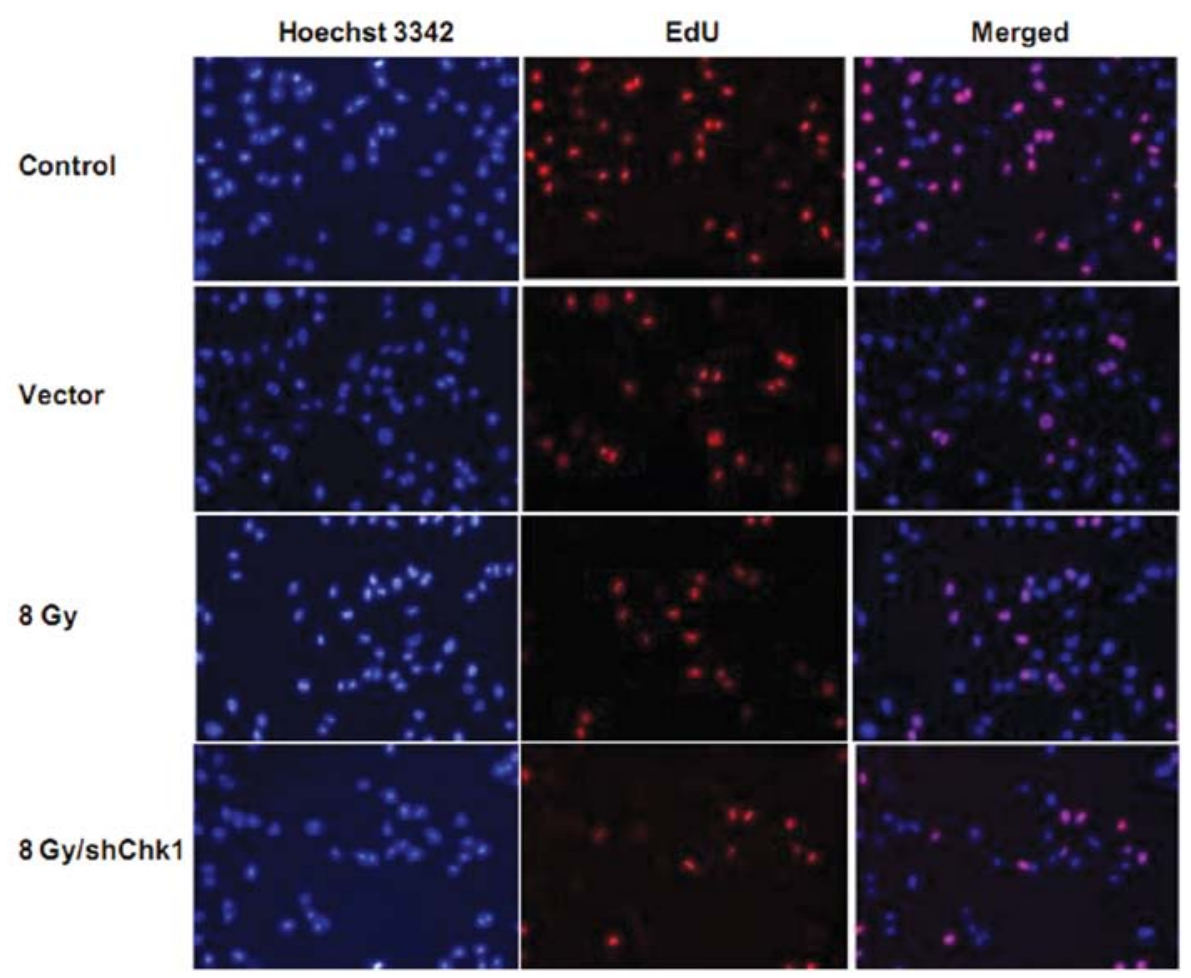

Figure 4. EdU assay analysis of the Chk1 knockdown effect on the proliferation of the sorted $\mathrm{CD} 133^{+} \mathrm{CD} 44^{+}$cells in vitro. The proliferation rate in the Chk1 knockdown plus radiation group was significantly lower than that in the other groups. The EdU assay demonstrated that Chk1 knockdown radiosensitized the sorted $\mathrm{CD} 133^{+} \mathrm{CD} 44^{+}$cells in vitro.

Chkl knockdown radiosensitizes prostate cancer stem cells. In order to investigate the effect of Chk1 knockdown on the radiosensitivity of $\mathrm{CD} 133^{+} \mathrm{CD} 44^{+}$cells, EdU cell proliferation assay was performed. Chk1 knockdown cells, vector cells and control cells were radiated at a dose of $8 \mathrm{~Gy}$. As shown in Fig. 4, $72 \mathrm{~h}$ after radiation, EdU assay showed that the growth 

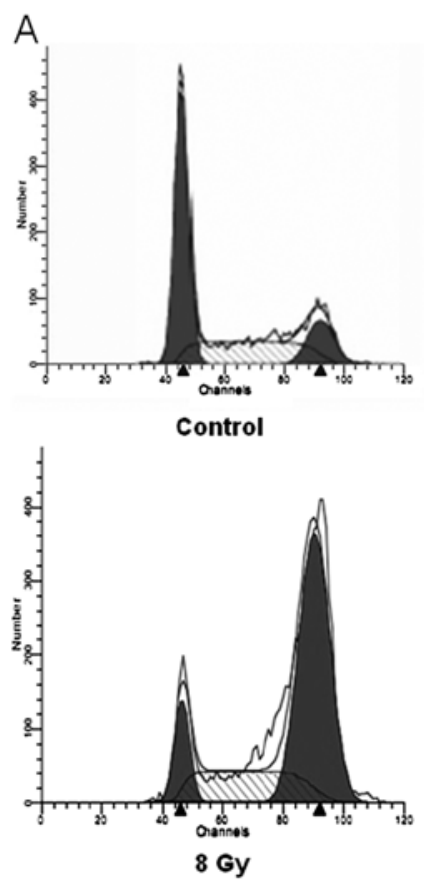

B

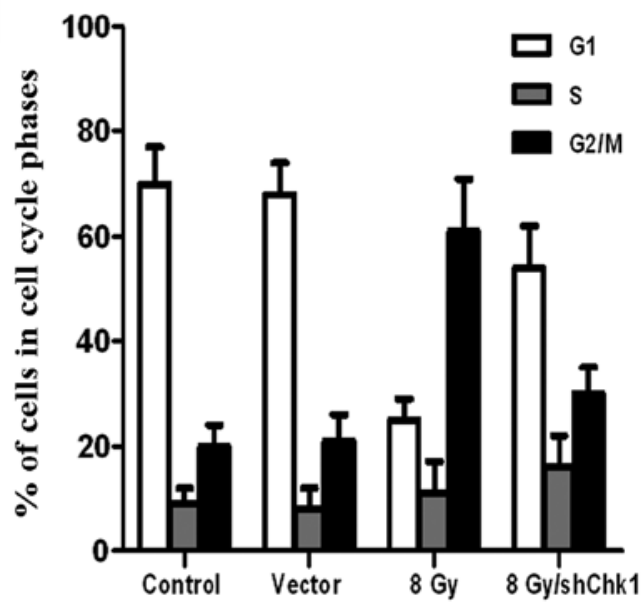

Figure 5. Cell cycle analysis of the sorted $\mathrm{CD} 133^{+} \mathrm{CD} 44^{+}$cells exposed to radiation (8 Gy) and/or Chk1 knockdown in vitro. (A) Representative histograms of cell cycle analysis of the cells in the control, vector, radiation and Chk1 knockdown plus radiation groups. (B) The bar graph demonstrates that Chk1 knockdown resulted in the abrogation of the radiation-induced G2/M arrest in the sorted CD133 ${ }^{+} \mathrm{CD} 44^{+}$cells. Data are representative of three independent experiments.
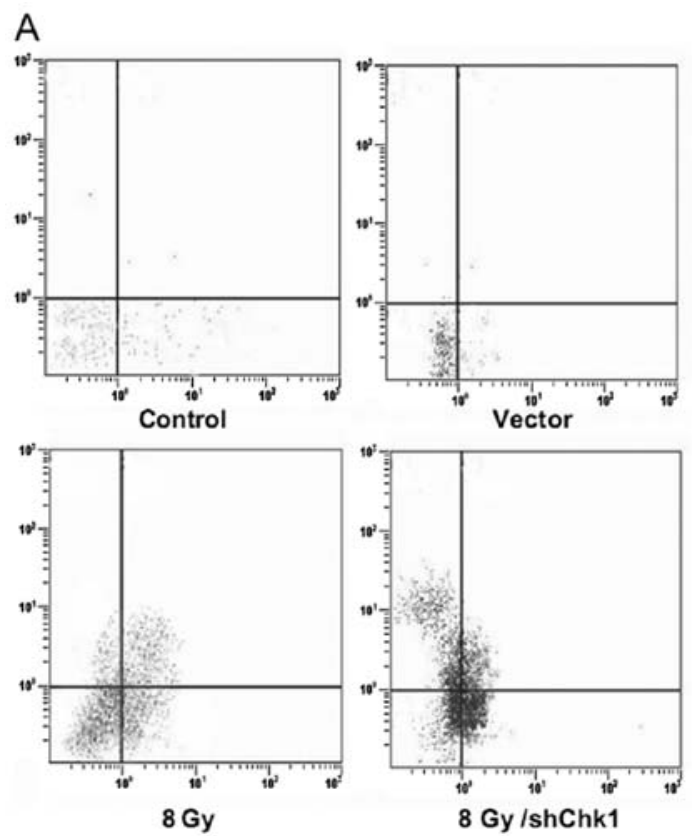

B

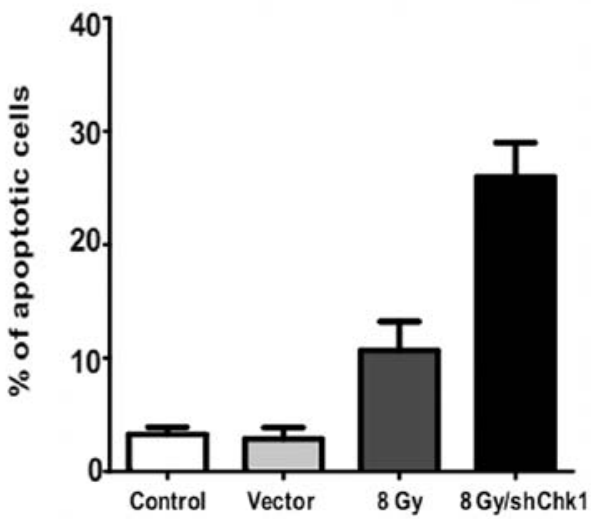

Figure 6. Flow cytometry analysis of apoptosis in the sorted CD133 ${ }^{+} \mathrm{CD} 44^{+}$cells exposed to radiation (8 Gy) and/or Chk1 knockdown in vitro. (A) Representative scatter plots of apoptosis analysis in cells in the control, vector, radiation and Chk1 knockdown plus radiation groups. (B) The bar graph indicates that Chk1 knockdown promoted radiation-induced apoptosis in $\mathrm{CD} 133^{+} \mathrm{CD} 44^{+}$cells. Data are representative of three independent experiments.

rate of the Chk1 knockdown cells was significantly lower than that of the vector and control cells after radiation. No obvious difference was observed between the growth rates of the vector and control cells (growth rate: shChk1 plus radiation group vs. control, vector and radiation groups, $9.23 \pm 2.15$ vs. 50.59 \pm 4.27 , $48.21 \pm 5.83$ and $21.58 \pm 4.92 \%$, respectively; $\mathrm{P}<0.05$ ).
As $\gamma-\mathrm{H} 2 \mathrm{AX}$ is considered an indicator of DNA damage (25), in order to further determine the effects of Chk1 knockdown on DNA damage in $\mathrm{CD} 133{ }^{+} \mathrm{CD} 44^{+}$cells, we measured $\gamma-\mathrm{H} 2 \mathrm{AX}$ protein expression in the different groups of cells. Western blot analysis showed that radiation resulted in a moderate increase in $\gamma$-H2AX protein expression in the $\mathrm{CD} 133{ }^{+} \mathrm{CD} 44^{+}$ 

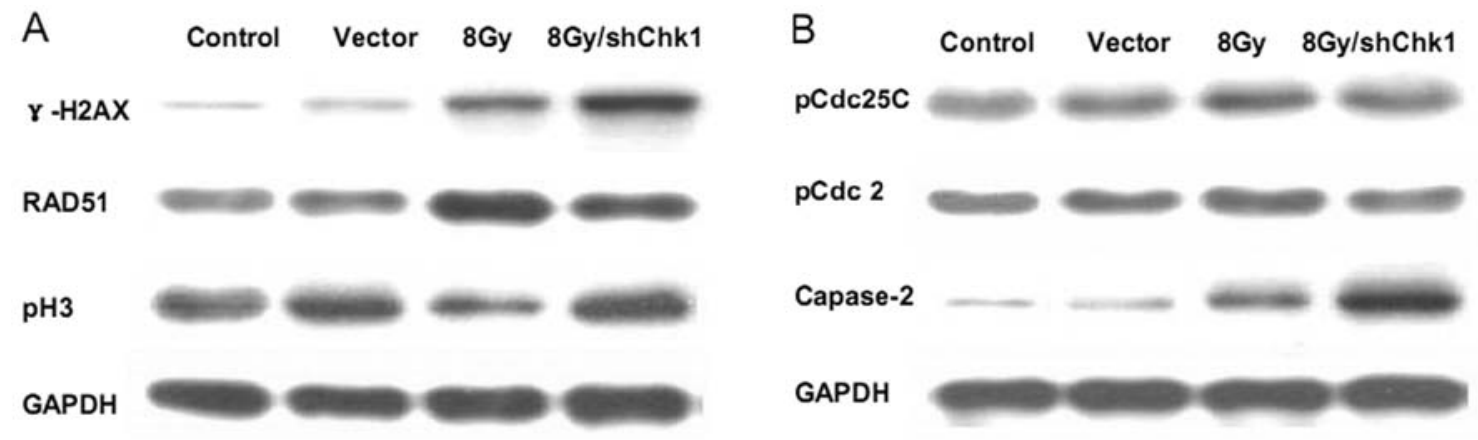

Figure 7. Representative western blots showing the changes in the expression of $\gamma-\mathrm{H} 2 \mathrm{AX}, \mathrm{RAD} 51, \mathrm{pH} 3, \mathrm{Cdc} 25 \mathrm{C}, \mathrm{Cdc} 2$ and caspase- 2 in the sorted CD133 ${ }^{+} \mathrm{CD} 44^{+}$ cells exposed to radiation ( $8 \mathrm{~Gy}$ ) and/or Chk1 knockdown in vitro. GAPDH served as the internal control. The results from western blot analysis suggested that the Chk1 knockdown accelerated the radiation-induced $\gamma$-H2AX and caspase-2 accumulation, abrogated the radiation-induced RAD51, Cdc25C and Cdc2 upregulation, and reversed the radiation-induced $\mathrm{pH} 3$ downregulation.

cells, while Chk1 knockdown significantly accelerated the radiation-induced accumulation of $\gamma$-H2AX protein expression (Fig. 7A). These results indicated that Chk1 knockdown significantly exacerbated the radiation-induced DNA damage in $\mathrm{CD} 133^{+} \mathrm{CD} 44^{+}$cells and sensitized the $\mathrm{CD} 133^{+} \mathrm{CD} 44^{+}$cells to radiation.

Chk1 knockdown abrogates radiation-induced cell cycle arrest and facilitates radiation-induced apoptosis. Chk1 knockdown, vector and control cells were radiated at dose of $8 \mathrm{~Gy}$. Another group of $\mathrm{CD} 133^{+} \mathrm{CD} 44^{+}$cells were cultured as the untreated controls without radiation. After $48 \mathrm{~h}$, flow cytometry was used to examine the cell cycle distribution and cell apoptosis in the four groups (Figs. 5 and 6). Compared to the untreated control cells, radiation resulted in a high accumulation of $\mathrm{CD}_{133}{ }^{+} \mathrm{CD} 44^{+}$cells in the $\mathrm{G} 2 / \mathrm{M}$ phase, while radiation only caused a slight $\mathrm{G} 2 / \mathrm{M}$ phase accumulation in the Chk1 knockdown $\mathrm{CD} 133{ }^{+} \mathrm{CD} 44^{+}$cells (percentage of cells in the $\mathrm{G} 2 / \mathrm{M}$ phase: shChk1 plus radiation group vs. control, vector and radiation groups, $32.13 \pm 4.54$ vs. $20.85 \pm 3.27$, $21.64 \pm 4.91$ and $62.43 \pm 8.12 \%$, respectively; $\mathrm{P}<0.05$ ). In addition, the Chk1 knockdown $\mathrm{CD} 133^{+} \mathrm{CD} 44^{+}$cells displayed a significantly higher apoptotic rate than the other groups which received radiation (apoptotic percentage: shChk1 plus radiation group vs. control, vector and radiation groups, $26.47 \pm 4.31$ vs. $3.35 \pm 0.47,3.21 \pm 0.82$ and $12.28 \pm 3.63 \%$, respectively; $\mathrm{P}<0.05$ ).

Since histone H3 becomes phosphorylated during mitosis, the phosphorylation of histone $\mathrm{H} 3(\mathrm{pH} 3)$ has traditionally been recognized as a marker of cells in mitosis (26). Therefore, the effect of Chk1 knockdown on $\mathrm{pH} 3$ expression in radiated $\mathrm{CD} 133^{+} \mathrm{CD} 44^{+}$cells was determined (Fig. 7A). We found that radiation decreased $\mathrm{pH} 3$ expression in $\mathrm{CD} 133^{+} \mathrm{CD} 44^{+}$cells, while Chk1 knockdown reversed the downregulation of $\mathrm{pH} 3$ in response to radiation, which indicates that $\mathrm{Chk} 1$ knockdown may abrogate the radiation-induced G2/M checkpoint and force the cells into premature cell cycle progression as evidenced by the renewal of mitotic progression. As RAD51 is a protein marker associated with DNA damage repair $(27,28)$, we determined RAD51 protein expression and found decreased RAD51 protein accumulation in the radiated Chk1 knockdown $\mathrm{CD} 133^{+} \mathrm{CD} 44^{+}$ cells (Fig. 7A). These results suggest that Chk1 knockdown enhances the efficacy of radiation therapy in $\mathrm{CD} 133{ }^{+} \mathrm{CD} 44^{+}$cells by modifying the cell cycle, DNA damage repair ability and apoptosis activity.

Chk1 knockdown not only reduces the radiation-induced phosphorylation of $\mathrm{Cdc} 25 \mathrm{C}$ and $\mathrm{Cdc} 2$ but also increases the cleavage of caspase-2. pCdc $25 \mathrm{C}$ and $\mathrm{pCdc} 2$ have been reported to be involved in Chk1-mediated cell cycle arrest (29-31), while caspase-2 has been associated with Chk1-mediated apoptosis (32). Therefore, in order to further explore the mechanistic bases of Chk1 knockdown in $\mathrm{CD} 133^{+} \mathrm{CD} 44^{+}$cells, we determined the expression of these proteins in our study using western blot analysis (Fig. 7B). After radiation exprosure, the $\mathrm{CD} 133^{+} \mathrm{CD} 44^{+}$ cells demonstrated increased $\mathrm{Cdc} 25 \mathrm{C}$ and $\mathrm{Cdc} 2$ phosphorylation, while the Chk1 knockdown reduced the radiation-induced phosphorylation of $\mathrm{Cdc} 25 \mathrm{C}$ and $\mathrm{Cdc} 2$. Furthermore, radiation increased the cleavage of caspase- 2 in the $\mathrm{CD} 133^{+} \mathrm{CD} 44^{+}$cells, while Chk1 knockdown significantly enhanced the radiationinduced caspase- 2 cleavage accumulation. These data suggest the involvement of the $\mathrm{Cdc} 25 \mathrm{C}-\mathrm{Cdc} 2$ pathway in the mechanism of Chk1-mediated cell cycle arrest and the association between Chk1-induced apoptosis and caspase-2 activation.

\section{Discussion}

Prostate cancer, one of the most common forms of neoplasia, is the second leading cause of cancer related mortality in the Western world $(1,4)$. Although radiation therapy has long been adopted as standard therapy for localized prostate cancer, the long-term effects are relatively poor due to the radioresistance of prostate cancer cells (3). Following radiation exposure, the survived and repopulating prostate cancer cells modulate many molecular pathways (mainly the Chk1 pathway) to overcome the radiation cytotoxic effects, leading to the development of radioresistance (33). The activation of the Chk1 pathway is crucial for the proper coordination of checkpoint and DNA repair processes, which allow for tumor cell survival following radiation $(27,33,34)$.

Based on these data, inhibiting Chk1 activity is believed to sensitize tumor cells to radiation and a considerable amount of evidence has confirmed that it is indeed the case in many tumor cell lines $(18,35,36)$. Cancer stem cells are more radioresistant than bulk cancer cells due to their preferential activation of the 
DNA damage checkpoint response and increasing DNA repair capacity $(11,12)$. Moreover, cancer stem cells can generate tumors in very small numbers (13). These properties significantly contribute to tumor regrowth and radioresistance. Thus, we hypothesized that Chk1 knockdown may enhance the radiation sensitivity of cancer stem cells, thereby providing a more efficient way for prostate cancer eradication.

The identification of prostate cancer stem cells has shown that prostate cancer stem cells express a number of cell surface markers, including CD44, CD133, intergrins, breast cancer resistance protein (BCRP) and Sca-1 $(20,24)$. The CD44+ prostate cancer cell population is enriched in tumorigenic progenitor cells $(23,24) . \mathrm{CD} 33^{+}$prostate cancer cells are more proliferative, clonogenic and tumorigenic than bulk prostate cancer cells (22). Since DU145 cells with stem-like properties have been reported to be enriched with CD133, CD44 and integrin $\alpha 2 \beta 1$ (24), we attempted to isolate prostate cancer cells from DU145 human prostate cancer cells. However, in our study, following isolation of the $\mathrm{CD} 133^{+} \mathrm{CD} 44^{+}$cells using magnetic microbeads, the integrin $\alpha 2 \beta 1$ isolation was not achieved, as the triple CD133-, CD44- and integrin- $\alpha 2 \beta 1$ positive DU145 cells always eventually died. In our preresearch, we also attempted, but failed to isolate prostate cancer cells from primary cell cultures of human prostate tumor tissues. These failures may be attributed to our limited cancer stem cell isolation and culture technology, as well as the imperfect framework for accessing tumor tissue samples. Thus, we only obtained the $\mathrm{CD} 133{ }^{+} \mathrm{CD} 44^{+}$subpopulation from the DU145 cells in our study. Apart from isolation, we also identified the cancer stem cell properties of the $\mathrm{CD} 133^{+} \mathrm{CD} 44^{+}$cells obtained in our study. The isolated $\mathrm{CD} 1333^{+} \mathrm{CD} 44^{+}$cells were able to generate prostaspheres, differentiated into cells with a morphology similar to unsorted DU145 cells and, most importantly, formed tumors on transplantation with a small number of cells. Since cancer stem cells have the capacity for self-renewal, multilineage differentiation and maintaining proliferation, our data indicate that $\mathrm{CD} 1333^{+} \mathrm{CD} 44^{+}$cells derived from DU145 cells have cancer stem cell properties and are responsible for the development of prostate cancer.

In this study, we transiently transfected $\mathrm{CD} 133{ }^{+} \mathrm{CD} 44^{+}$cells using Chk1 shRNA in order to explore the potential radiosensitizing effect of Chk1 knockdown on prostate cancer stem cells. We found that Chk1 knockdown decreased RAD51 expression, abrogated the G2/M checkpoint and increased $\gamma$-H2AX expression and apoptosis in $\mathrm{CD} 133^{+} \mathrm{CD} 44^{+}$cells following radiation. These data indicate that Chk1 knockdown potentiates the cytotoxic effects of radiation by abrogating the G2/M checkpoint, inhibiting DNA damage repair and promoting premature mitosis, which in turn results in increased apoptosis. Moreover, the abrogation of radiation-induced G2/M arrest and the promotion of radiation-induced apoptosis by Chk1 knockdown was associated with the inactivation of phosphorylated Cdc $25 \mathrm{C}$ and $\mathrm{Cdc} 2$, as well as the activation of caspase-2. These results are consistent with those from previous studies supporting the key role of Chk1 inhibition in radiosensitizing a variety of tumor cell lines $(5,17)$.

Our study had certain inherent limitations. Our data only provided in vitro evidence of the radiosensitizing effect of Chk1 knockdown on the isolated $\mathrm{CD} 133{ }^{+} \mathrm{CD} 44^{+}$prostate cancer stem cells, lacking direct evidence in vivo, as the in vivo study is currenlty ongoing on in our laboratory. Nevertheless, the present study suggests for the first time, that Chk1 knockdown radiosensitizes prostate cancer stem cells. The specific molecular mechanism behind the radiosensitizing effects of Chk1 knockdown on prostate cancer stem cells may be linked to the abrogation of the $\mathrm{G} 2 / \mathrm{M}$ checkpoint, the inhibition of DNA damage repair and the promotion of apoptosis. Since the safety of tumor-directed gene therapy has been supported by various clinical trials and cancer stem cells have a potent tumor-initiating capacity, as well as intrinsic radioresistance (9,37-40), enhancing the radiation sensitivity of cancer stem cells via Chk1 knockdown may prove to be a novel therapeutic approach to improve the poor prognosis of radioresistant prostate cancer patients. Further research is warranted to define the optimal clinical settings where such a therapeutic strategy can be applied.

\section{References}

1. Neppl-Huber C, Zappa M, Coebergh JW, et al: Changes in incidence, survival and mortality of prostate cancer in Europe and the United States in the PSA era: additional diagnoses and avoided deaths. Ann Oncol 23: 1325-1334, 2012.

2. Heidenreich A, Bellmunt J, Bolla M, et al: EAU guidelines on prostate cancer. Part 1: screening, diagnosis, and treatment of clinically localised disease. Eur Urol 59: 61-71, 2011.

3. Bonkhoff H: Factors implicated in radiation therapy failure and radiosensitization of prostate cancer. Prostate Cancer 2012: $593241,2012$.

4. Beckendorf V, Guerif S, Le PE, et al: 70 Gy versus 80 Gy in localized prostate cancer: 5-year results of GETUG 06 randomized trial. Int J Radiat Oncol Biol Phys 80: 1056-1063, 2011.

5. Merry C, Fu K, Wang J, Yeh IJ and Zhang Y: Targeting the checkpoint kinase Chk1 in cancer therapy. Cell Cycle 9: 279-283, 2010.

6. Stracker TH, Usui T and Petrini JH: Taking the time to make important decisions: the checkpoint effector kinases Chk1 and Chk2 and the DNA damage response. DNA Repair 8: 1047-1054, 2009.

7. Jackson SP and Bartek J: The DNA-damage response in human biology and disease. Nature 461: 1071-1078, 2009.

8. Diehn M and Clarke MF: Cancer stem cells and radiotherapy: new insights into tumor radioresistance. J Natl Cancer Inst 98: $1755-1757,2006$

9. Baumann M, Krause M and Hill R: Exploring the role of cancer stem cells in radioresistance. Nat Rev Cancer 8: 545-554, 2008.

10. Hittelman WN, Liao Y, Wang L and Milas L: Are cancer stem cells radioresistant. Future Oncol 6: 1563-1576, 2010.

11. Visvader JE and Lindeman GJ: Cancer stem cells in solid tumours: accumulating evidence and unresolved questions. Nat Rev Cancer 8: 755-768, 2008

12. Eyler CE and Rich JN: Survival of the fittest: cancer stem cells in therapeutic resistance and angiogenesis. J Clin Oncol 26: 2839-2845, 2008.

13. Wang G, Wang Z, Sarkar FH and Wei W: Targeting prostate cancer stem cells for cancer therapy. Discov Med 13: 135-142, 2012.

14. Maitland NJ and Collins AT: Prostate cancer stem cells: a new target for therapy. J Clin Oncol 26: 2862-2870, 2008.

15. Wu J, Lai G, Wan F, et al: Knockdown of checkpoint kinase 1 is associated with the increased radiosensitivity of glioblastoma stem-like cells. Tohoku J Exp Med 226: 267-274, 2012.

16. Xiao Z, Liu Q, Zhao B, Wu J and Lei T: Hypoxia induces hemorrhagic transformation in pituitary adenomas via the HIF-1a signaling pathway. Oncol Rep 26: 1457-1464, 2011.

17. Ma CX, Janetka JW and Piwnica-Worms H: Death by releasing the breaks: CHK1 inhibitors as cancer therapeutics. Trends Mol Med 17: 88-96, 2011.

18. Carrassa L and Damia G: Unleashing Chk1 in cancer therapy. Cell Cycle 10: 2121-2128, 2011.

19. Chen Y and Sanchez Y: Chk1 in the DNA damage response: conserved roles from yeasts to mammals. DNA Repair 3: 1025-1032, 2004

20. Lang SH, Frame FM and Collins AT: Prostate cancer stem cells. J Pathol 217: 299-306, 2009. 
21. Collins AT, Berry PA, Hyde C, Stower MJ and Maitland NJ: Prospective identification of tumorigenic prostate cancer stem cells. Cancer Res 65: 10946-10951, 2005.

22. Li C, Heidt DG, Dalerba P, et al: Identification of pancreatic cancer stem cells. Cancer Res 67: 1030-1037, 2007.

23. Tang DG, Patrawala L, Calhoun T, et al: Prostate cancer stem/ progenitor cells: identification, characterization, and implications. Mol Carcinog 46: 1-14, 2007.

24. Wei C, Guomin W, Yujun L and Ruizhe Q: Cancer stem-like cells in human prostate carcinoma cells DU145: the seeds of the cell line. Cancer Biol Ther 6: 763-768, 2007.

25. Syljuasen RG, Sorensen CS, Hansen LT, et al: Inhibition of human Chk1 causes increased initiation of DNA replication, phosphorylation of ATR targets, and DNA breakage. Mol Cell Biol 25: 3553-3562, 2005.

26. Binder A and Bohm L: Influence of irradiation and pentoxifylline on histone $\mathrm{H} 3$ phosphorylation in human tumour cell lines. Cell Prolif 35: 37-47, 2002.

27. Sorensen CS, Hansen LT, Dziegielewski J, et al: The cell-cycle checkpoint kinase Chk1 is required for mammalian homologous recombination repair. Nat Cell Biol 7: 195-201, 2005.

28. Bahassi EM, Ovesen JL, Riesenberg AL, Bernstein WZ, Hasty PE and Stambrook PJ: The checkpoint kinases Chk1 and Chk2 regulate the functional associations between hBRCA2 and Rad51 in response to DNA damage. Oncogene 27: 3977-3985, 2008.

29. Xiao Z, Chen Z, Gunasekera $\mathrm{AH}$, et al: Chk1 mediates $\mathrm{S}$ and $\mathrm{G} 2$ arrests through $\mathrm{Cdc} 25 \mathrm{~A}$ degradation in response to DNA-damaging agents. J Biol Chem 278: 21767-21773, 2003

30. Sanchez Y, Wong C, Thoma RS, et al: Conservation of the Chk1 checkpoint pathway in mammals: linkage of DNA damage to Cdk regulation through Cdc25. Science 277: 1497-1501, 1997.

31. Sorensen CS, Melixetian M, Klein DK and Helin K: NEK11: linking CHK1 and CDC25A in DNA damage checkpoint signaling. Cell Cycle 9: 450-455, 2010.
32. Sidi S, Sanda T, Kennedy RD, et al: Chk1 suppresses a caspase-2 apoptotic response to DNA damage that bypasses $\mathrm{p} 53, \mathrm{Bcl}-2$, and caspase-3. Cell 133: 864-877, 2008.

33. Dumont F, Altmeyer A and Bischoff P: Radiosensitising agents for the radiotherapy of cancer: novel molecularly targeted approaches. Expert Opin Ther Pat 19: 775-799, 2009.

34. Yang H, Yoon SJ, Jin J, et al: Inhibition of checkpoint kinase 1 sensitizes lung cancer brain metastases to radiotherapy. Biochem Biophys Res Commun 406: 53-58, 2011.

35. Meuth M: Chk1 suppressed cell death. Cell Div 5: 21, 2010.

36. Smith J, Tho LM, Xu N and Gillespie DA: The ATM-Chk2 and ATR-Chk1 pathways in DNA damage signaling and cancer. Adv Cancer Res 108: 73-112, 2010.

37. Gao Q, Zhou J, Huang X, et al: Selective targeting of checkpoint kinase 1 in tumor cells with a novel potent oncolytic adenovirus. Mol Ther 13: 928-937, 2006.

38. Freytag SO, Stricker H, Pegg J, et al: Phase I study of replicationcompetent adenovirus-mediated double-suicide gene therapy in combination with conventional-dose three-dimensional conformal radiation therapy for the treatment of newly diagnosed, intermediate- to high-risk prostate cancer. Cancer Res 63: 7497-7506, 2003.

39. Geoerger B, van Beusechem VW, Opolon P, et al: Expression of p53, or targeting towards EGFR, enhances the oncolytic potency of conditionally replicative adenovirus against neuroblastoma. J Gene Med 7: 584-594, 2005.

40. Tsuruta Y, Pereboeva L, Breidenbach M, et al: A fiber-modified mesothelin promoter-based conditionally replicating adenovirus for treatment of ovarian cancer. Clin Cancer Res 14: 3582-3588, 2008. 